\title{
Hallmarks of Cancer-Related Newly Prognostic Factors of Oral Squamous Cell Carcinoma
}

\author{
Tomonori Sasahira ${ }^{1, *(1)}$ and Tadaaki Kirita ${ }^{2}$ (D) \\ 1 Department of Molecular Pathology, Nara Medical University, 840 Shijo-cho, Kashihara, \\ Nara 634-8521, Japan \\ 2 Department of Oral and Maxillofacial Surgery, Nara Medical University, 840 Shijo-cho, Kashihara, \\ Nara 634-8521, Japan; tkirita@naramed-u.ac.jp \\ * Correspondence: sasa@naramed-u.ac.jp; Tel.: +81-744-29-8849; Fax: +81-744-25-7308
}

Received: 28 July 2018; Accepted: 15 August 2018; Published: 16 August 2018

\begin{abstract}
Head and neck cancer, including oral squamous cell carcinoma (OSCC), is the sixth leading malignancy worldwide. OSCC is an aggressive tumor and its prognosis has exhibited little improvement in the last three decades. Comprehensive elucidation of OSCC's molecular mechanism is imperative for early detection and treatment, improving patient survival. Based on broadly accepted notions, OSCC arises from multiple genetic alterations caused by chronic exposure to carcinogens. In 2011, research revealed 10 key alterations fundamental to cancer cell development: sustaining proliferative signaling, evading growth suppressors, avoiding immune destruction, activating invasion and metastasis, tumor-promoting inflammation, enabling replicative immortality, inducing angiogenesis, genome instability and mutation, resisting cell death, and deregulating energetics. This review describes molecular pathological findings on conventional and novel hallmarks of OSCC prognostic factors. In addition, the review summarizes the functions and roles of several molecules as novel OSCC prognosticators.
\end{abstract}

Keywords: oral cancer; hallmarks of cancer; prognostic factors

\section{Introduction}

Head and neck cancer, including oral squamous cell carcinoma (OSCC), is the sixth leading cancer worldwide, with an estimated 300,400 cases and 145,400 OSCC-related deaths occurring in 2012 [1]. OSCC is one of the leading causes of morbidity and mortality in Melanesia, South Central Asia, and Central and Eastern Europe [1]. It arises anywhere in the oral cavity, including the tongue, upper and lower gingiva, oral floor, palate, and buccal mucosa. Despite advances in cancer diagnosis and treatment, the overall 5-year survival rate for OSCC remains the lowest among malignancies and, in fact, has been $<50 \%$ for the last three decades [2]. Anatomically, OSCC of the tongue and gingiva is prone to invade the deeper muscles and jawbone, respectively. In addition, OSCC tends to cause cervical lymph node metastasis because the lymphatic vessels in the oral cavity are rich and comprise numerous anastomoses [3]. Furthermore, OSCC often causes dysfunctions in chewing and swallowing, as well as speech and esthetic disorders, which can worsen patients' quality of life [4]. Hence, the recurrent potential of OSCC is considered to be closely associated with the local expansion and nodal metastasis of tumor cells. However, specific molecular OSCC prognosticators have only been partially identified.

Recently, Hanahan and Weinberg [5] proposed that the following "10 hallmarks of cancer" are pivotal in tumor progression: sustaining proliferative signaling, evading growth suppressors, avoiding immune destruction, activating invasion and metastasis, tumor-promoting inflammation, enabling replicative immortality, inducing angiogenesis, genome instability and mutation, resisting cell death, 
and deregulating energetics. Figure 1 presents a schematic illustration of this model, assuming it applies to OSCC prognostication. This review aims to summarize the general major OSCC prognosticators based on the hallmarks of cancer. In addition, the review describes our latest molecular pathological findings regarding OSCC prognostic predictors.

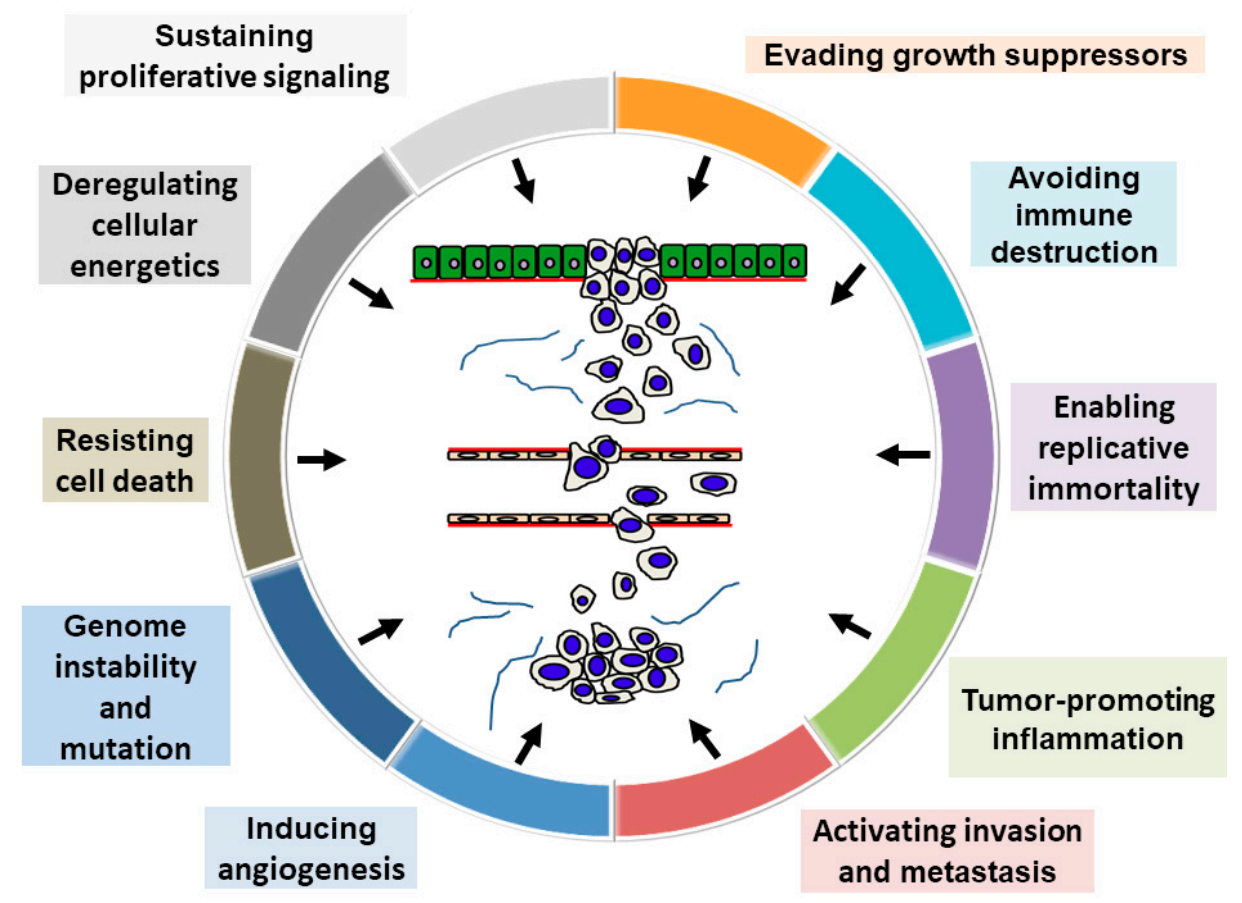

Figure 1. Schema of the hallmarks of cancer. This schema presents the 10 hallmark capabilities as follows: sustained proliferative signals, evasion of growth suppressors, resistance to cell death, replicative immortality, induction of angiogenesis, activation of invasion and metastasis, avoidance of immune destruction, deregulation of cellular energetics, genome instability and mutation, and tumor-promoting inflammation. Adapted reproduction with permission from Ref. [4].

\section{Hallmarks of Cancer-Related Conventional Principal Prognostic Factors of OSCC}

\subsection{Sustaining Proliferative Signaling}

Healthy cells regulate growth signals through soluble and membrane-bound growth factors; however, cancer cells are characterized by autonomous, chaotic growth because of deregulated growth signals [6]. The epidermal growth factor (EGF) family are transmembrane tyrosine kinase receptors comprising epidermal growth factor receptor (EGFR) or human epidermal growth factor receptor 1 (HER1), HER2, HER3, and HER4 [7]. Studies have established a marked correlation between the EGFR, phosphorylated EGFR (pEGFR), HER2, or HER4 expression and the poor survival of OSCC patients [8-10]. The overexpression of cyclin $\mathrm{D} 1$, a cell-cycle regulator from $\mathrm{G}_{1}$ to S-phase, also indicates low survival [11]. C-Met is another transmembrane tyrosine kinase receptor that is associated with the poor prognosis in OSCC patients through the activation of matrix metalloproteinase matrixins (MMP)-1, -2, and -9 [12]. In addition, the signal transducer and activator of transcription (STAT) family members are cytoplasmic transcription factors, and a recent study suggested that cases with phosphorylated STAT3 (pSTAT3) expression indicated the worst OSCC prognosis [13]. Furthermore, STAT3 and c-Met co-expression is involved in OSCC progression [14].

\subsection{Evading Growth Suppressors}

In cancer cells, several tumor-suppressor genes associated with antigrowth signals are inactivated by mutation, deletion, and methylation. It is well established that p53 is a genome guardian and plays a 
pivotal role in regulating the cell cycle, cellular differentiation, DNA repair, and apoptosis [15]. Somatic mutations in p53 are detected in $60-80 \%$ of OSCC and in early $10 \%$ of oral dysplasia [6]. Recently, Genome Wide Association Study data have shown that p53 is usually mutated in cases with human papillomavirus-negative OSCC [16]. Recently, the p53 mutation grading system, which classifies low-risk missense mutations, high-risk missense mutations, and other mutations have developed in head and neck cancer containing OSCC, and subgroups of high-risk p53 mutations are associated with decreased sensitivity to cisplatin, distant metastasis, extranodal extension, and poor prognosis [17-19]. The overall survival of p53-mutant OSCC patients is also markedly worse than that of patients with p53 wild-type [20]. In addition, the reduction of cell-cycle regulator p16 or p21 expression levels markedly correlated with poor prognosis [21,22]. Phosphatase and tensin homolog (PTEN) acts as a tumor repressor through negative feedback of the phosphoinositide 3-kinase (PI3K)-Akt-mammalian target of rapamycin (mTOR) pathway [23]. Moreover, PTEN inhibits insulin signaling by indirectly suppressing the phosphorylation of mitogen-activated protein kinase (MAPK) and blocking insulin receptor substrate 1 (IRS-1) phosphorylation [23]. In OSCC, the absence of PTEN expression predicts unfavorable prognosis [24]. Incidentally, PTEN is inactivated due to gene methylation because PTEN mRNA restoration is observed post-treatment with 5-aza-2'-deoxycytidine (5-Aza-dc), a demethylation reagent, in human OSCC-derived cells [25].

\subsection{Avoiding Immune Destruction}

Among lymphocytes, CD8 ${ }^{+}$cytotoxic $\mathrm{T}$ cells (CTL) serve as antitumor immunity cells in cooperation with $\mathrm{CD} 4^{+} \mathrm{T}$ helper type 1 cells (Th1 cells). However, chemokines can recruit $\mathrm{CD} 4^{+}$ Th2 cells and $\mathrm{CD}^{+} \mathrm{T}$ regulatory (Treg) cells into the tumor microenvironment, causing inhibited CTL antitumor responses [26]. Previously, we reported that the melanoma inhibitory activity 2 (MIA2) in OSCC is promoted by a disturbance in the tumor immunity through the suppression of CTL, Th1 cells, and CD40L ${ }^{+}$and granzyme $\mathrm{B}^{+} \mathrm{T}$ lymphocytes and relative increment in Treg cells [4,27]. In addition, tumor-infiltrating myeloid cells, with the co-expressing macrophage marker $\mathrm{CD} 11 \mathrm{~b}$ and the neutrophil marker Gr1, have been reported to suppress CTL and natural killer (NK) cell activity [5]. Reportedly, chemokine (C-X-C motif) ligand 9 (CXCL9) is an interferon- $\gamma$ inducible chemokine, and higher CXCL9 serum levels are independent predictors of the overall and disease-free survival in OSCC patients OSCC [28]. Furthermore, secretion and expression levels of interleukin (IL)-8 are implicated in poor clinical outcomes through the generation of CD163-positive M2 macrophages in OSCC [29]. Programmed cell death ligand 1 (PD-L1) and its receptor PD-1 play a central role in tumor immune escape and the formation of a tumor microenvironment [30]. Overexpression of PD-L1 on tumor cells and PD-1 on tumor-infiltrating lymphocytes is correlated with poor disease outcome in various human cancers [31]. Antagonists of PD-1 and PD-L1 have demonstrated clinical utility in several types of advanced malignancies [32]. In OSCC, PD-L1/PD-1 expression is a useful predictor for nodal metastasis and poor prognosis in OSCC cases [33].

\subsection{Activating Invasion and Metastasis}

OSCC metastasis primarily occurs through the cervical lymph nodes on the affected side. The following sequential steps are fundamental to invasion and metastasis of cancer cells:

1. Declined adhesion and detachment of cancer cells;

2. Disruption of the basal membrane;

3. Acquisition of cancer cell movement and stromal infiltration;

4. Intravasation;

5. Intravascular migration;

6. Extravasation;

7. Cancer cell growth in the metastatic foci [6]. 
In addition, cancer cells are unbound by adhesion molecule abnormalities. E-cadherin, which plays a pivotal role in maintaining cell-to-cell adhesions in normal epithelial cells, correlates with poorer OSCC prognosis [34]. Likewise, integrins, which are heterodimeric cellular transmembrane proteins, are also crucial adhesion molecules mediating cell-to-cell and cell-to-extracellular matrix interactions [6]. The overexpression of integrin $\alpha \mathrm{v} \beta 6$ is an unfavorable clinical prognostic factor in OSCC patients [35]. In addition, the prognosis of patients with integrin- $\alpha 7$ expression is markedly worse than that of patients without the integrin $\alpha 7$ expression [36]. MMPs are secretory proteolytic enzymes which are involved in extracellular matrix modulation and the destruction of the basement membrane [6]. Recent studies suggested that OSCC cases with expression of MMP-7, -11, -13, or -21 exhibit a markedly lower survival rate [37-40]. Similarly, the epithelial-mesenchymal transition (EMT), characterized by a reduction of epithelial propensities and the acquisition of a mesenchymal phenotype, plays a pivotal role in the invasion and metastasis of cancer cells. Reportedly, critical EMT transducers are transforming growth factor- $\beta$ (TGF- $\beta$ ), Wnt, Notch, interleukin-like EMT-inducer, hepatocyte growth factor, EGF, and platelet-derived growth factor (PDGF) [41]. Moreover, tumor cells with induced EMT exhibit a decline in the epithelial cell-to-cell attachment by repression of E-cadherin, ZO-1, occludin, and others, and the overexpression of mesenchymal markers, including smooth muscle actin, vimentin, $\mathrm{N}$-cadherin, and desmin [41]. Furthermore, the upregulation of transcription factors, such as Snail, Slug, Twist, and ZEB1/2, is fundamental to retention of the EMT status in cancer cells [6,41]. Consequently, EMT gain contributes to poorer outcomes for OSCC patients [42].

\subsection{Tumor-Promoting Inflammation}

Apparently, inflammatory cells promote the development, advancement, and metastasis of cancer by producing tumor-promoting cytokines. Inflammation can alter the tumor microenvironment by inducing growth, survival, proangiogenic factors, and reactive oxygen species. It can also modify the extracellular matrix, thereby promoting angiogenesis, invasion, and metastasis [5]. In addition, stromal fibroblasts may play a vital role in the desmoplastic reaction to cancer by secreting the extracellular matrix. Eltohami et al. [43] reported that the systemic inflammatory score (SIS), which is based on the sum of albumin and the lymphocyte-to-monocyte ratio, is closely associated with local progression (T grade), clinical stage, tumor depth, perineural invasion, extranodal extension, and poor survival. Cyclooxygenase-2 (COX-2) is a pro-inflammatory enzyme that converts arachidonic acid to prostaglandins, promoting invasion and OSCC cell metastasis [44]. The COX-2 expression is an independent prognostic factor by immunohistochemistry [45]. Furthermore, the IL-6 overexpression, which is a pleiotropic cytokine, in OSCC cells is a good predictor of poor response to chemo/radiotherapy and poor prognosis [46].

\subsection{Enabling Replicative Immortality}

Telomeres are tandemly repeated DNA sequences with 5'-TTAGGG-3' present at the linear ends of chromosomes; these elements are bound to specific proteins, including telomeric repeat factors 1 and 2 (TRF1 and TRF2), TRF1-interacting nuclear factor 2 (TIN2), repressor activator protein 1 (RAP1), protection of telomeres (POT1), and POT1-interacting protein (TPP1) [47]. Reportedly, the telomere length is maintained by telomerase, and its activity is regulated by the expression of human telomerase reverse transcriptase (hTERT), as the catalytic subunit of telomerase [48]. In addition, telomere plays a crucial role in OSCC tumorigenesis and progression. Telomere dysfunction is a valid predictor of radioresistance in OSCC cells [49]. Moreover, high-expression levels of hTERT are involved in the oral carcinogenesis at an early phase and unfavorable outcomes for OSCC patients [50]. Furthermore, TRF2 immunopositivity, which interacts with the distal ends of chromosomes to protect telomere, is a good marker of poor prognosis [51]. 


\subsection{Inducing Angiogenesis}

Although cancer causes tissue hypoxia, the provision of oxygen and nutrients and withdrawal of waste products are essential for tumor cells. Angiogenesis, the formation of new blood vessels, and lymphangiogenesis, the proliferation of new lymphatic vessels, are essential for the growth, invasion, and metastasis of cancer cells [52]. A recent study suggested that antiangiogenic gene therapy might be useful for the prevention and early treatment of malignancies [53]. Typically, compared to normal vessels, neoplastic vessels are leaky and dilated, lack pericytes, and can be attenuated for anticancer drug delivery [52,54]. However, high microvessel density (MVD) and lymphovessel density (LVD) are markedly related to $T$ grade, clinical stage, nodal metastasis, local recurrence, and poor outcomes [52]. In addition, family members of vascular endothelial growth factor (VEGF), including VEGF-A, -C, and -D, play a central role in the tumor angiogenesis and lymphangiogenesis [6,52]. In OSCC, expression levels of VEGF-A, -C, or -D are strongly related to only angiogenesis/lymphangiogenesis but also poorer outcomes $[52,55,56]$.

\subsection{Genome Instability and Mutation}

Broadly, OSCC arises from multiple genetic and epigenetic alterations triggered by the chronic exposure to carcinogens such as alcohol, smoking, toxic chemical substance, viral infections, and inflammation; these genetic alterations include deletions, point mutations, promoter methylation, and oncogene amplification. They also inactivate tumor-suppressor genes [6]. Loss of heterozygosity $(\mathrm{LOH})$ on chromosomes $3 p, 9 p$ (inactivation of $p 16$ ), and 17p (inactivation of $p 53$ ) correlates to early-phase oral carcinogenesis; conversely, genetic alterations on chromosomes 4q, 8p, 11q, and 13q correlates with late-phase oral carcinogenesis [4]. Recent genome-wide LOH and DNA copy-number aberration analysis revealed that regions on $4 q, 8 p, 9 p$ and 11q play a vital role in the disease-specific survival of OSCC patients [57]. In addition, $\mathrm{LOH}$ on 1q21.3 is an independent prognostic factor in OSCC [58]. A high-throughput, genome-wide analysis using a next-generation sequencer provides a comprehensive platform to elucidate an overview of gene expression and mutation [59]. Recent reporting indicated that $p 16$, protocadherin FAT1, p53, caspase-8, PI3K, Notch1, histone-lysine $\mathrm{N}$-methyltransferase 2D (KMT2D), nuclear receptor binding SET domain protein 1 (NSD1), and H-ras are frequently mutated genes in head and neck SCC including OSCC [16]. Furthermore, the subgroup of OSCC cases with favorable clinical outcomes represents infrequent copy-number alterations combined with the activation of $H$-ras or PI3K, wild-type $p 53$, and the inactivation of caspase-8 and Notch1 [16]. FAT1 regulates the migration and invasion of OSCC cells through the localization of $\beta$-catenin [60]. The PI3K/AKT/mTOR signaling pathway is associated with tumor growth, survival, metastasis, and treatment-resistant in OSCC [61]. Notch 1 has an oncogenic and tumor suppressive function in OSCC and its role is still controversial [62]. KMT2D and NSD1 are chromatin remodeling gene and their alterations are strongly associated with sensitivity to aurora kinase inhibition and widespread genome hypomethylation in head and neck SCC, respectively [63,64]. High frequency of $H$-Ras mutation is detected in Asian populations associated with betel nut chewing [65].

\subsection{Resisting Cell Death}

The escape from apoptosis allows cancer cells to survive longer, providing more time for accumulating mutations [66]. Apoptosis can occur through both extrinsic (receptor-initiated death) and intrinsic (mitochondrial) pathways. The extrinsic pathway is triggered by the binding of tumor necrosis factor- $\gamma$ (TNF $\gamma$ ) or Fas to TNF-related apoptosis-inducing ligand (TRAIL) or Fas ligand (FasL), thus activating caspase- 8 and -3 . The intrinsic pathway is regulated the by B-cell lymphoma-2 (Bcl-2) protein family, containing Bcl-2, Bcl-2-associated X protein (Bax), Bcl-2 homologous antagonist killer (Bak), and so on, through various stimuli, prompting the release of cytochrome $C$ and enhancing caspase- 9 and $-3[6,66]$. The $\mathrm{Bcl}-2$ overexpression is strongly related to the poor prognosis of OSCC patients [67]. Conversely, cases with the Bax or Bak overexpression exhibit a markedly better cancer-specific 
prognosis than those without the Bax or Bak expression $[67,68]$. Survivin is a member of the inhibitor of apoptosis protein (IAP) family and inhibits apoptosis by suppressing the activity of caspase-3, -7 , and -9 [69]. Although survivin is expressed on cytoplasm in normal human oral keratinocytes, nuclear translocation of survivin by acetylation is observed in OSCC cells [70]. Nuclear staining of survivin is also associated with clinical stage and poor prognosis in OSCC patients [70]. Moreover, cellular IAP2 (cIAP2), other member of the IAP family, is involved in 5-fluorouracil (5-FU) resistance and shorter overall survival periods in OSCC [71].

\subsection{Deregulating Energetics}

Under aerobic conditions, healthy cells produce adenosine triphosphate (ATP) from glucose in the mitochondria and oxidative phosphorylation in the electron transfer system. In addition, ATP is produced through the anaerobic glycolytic pathway, which breaks down glucose in the cytoplasm and produces lactic acid under anaerobic conditions [6]. However, cancer cells can produce energy through aerobic glycolysis in the presence of oxygen (Warburg effect) [5,72]. Most cancer cells enhance glycolysis uncoupled with the oxidative phosphorylation, although glycolysis yields lower amounts of ATP from glucose than the oxidative phosphorylation [73,74]. Glucose transporter 1 (GLUT-1) is a transmembrane protein regulating the transport and metabolism of glucose, and elevated GLUT1 expression levels are observed in many malignancies $[75,76]$. In OSCC, the GLUT1 overexpression causes resistance to radiotherapy and chemotherapy and, thus, poor prognosis $[77,78]$. Another crucial cellular energetics-related factor is hypoxia-inducible factor $1 \alpha$ (HIF1 $\alpha$ ), which modulates target gene transactivation under hypoxic conditions [79]. Previously, we reported that $\left[{ }^{18} \mathrm{~F}\right]$ fluoro-2-deoxyglucose-positron emission tomography (FDG-PET) imaging findings correlated with a therapeutic response to neoadjuvant chemoradiotherapy and immunohistochemical staining of HIF- $1 \alpha$ in patients with advanced OSCC [80]. Furthermore, the HIF1- $\alpha$ expression correlated with OSCC angiogenesis, lymphangiogenesis, and poor prognosis [81,82].

\section{Novel Prognosticators of OSCC}

We investigated the hallmarks of cancer-related molecules to elucidate the molecular mechanism of cancer development, invasion, metastasis, and prognosis. Here, we describe the functions of 12 new prognostic factors in OSCC (Table 1).

\section{1. $m i R-126$}

MicroRNAs (miRNAs) are noncoding small RNAs of approximately 18-25 nucleotides that regulate gene expression by binding to the 3 '-untranslated region (UTR) of the target mRNA [6]. The biosynthetic process of the mature miRNA can be explained as follows. Primary miRNA (pri-miRNA) is processed in the nucleus into precursor miRNA (pre-miRNA) by the RNase Drosha and DiGeorge syndrome critical region gene 8 (DCRG8). Pre-miRNA is exported to the cytoplasm by exportin-5 and processed into mature miRNA by the RNase Dicer. After integration into the RNA-induced silencing complex (RISC), the mature miRNA regulates the target gene mRNA expression [6]. Recently, meta-analyses have revealed that the upregulation of 9 miRNAs (miR-21, miR-455-5p, miR-155-5p, miR-372, miR-373, miR-29b, miR-1246, miR-196a, and miR-181) and the downregulation of 7 miRNAs (miR-204, miR-101, miR-32, miR-20a, miR-16, miR-17, and miR-125b) are strongly correlated with poor prognosis in OSCC patients [83]. Long noncoding RNA (lncRNA), a class of non-protein coding transcripts longer than 200 nucleotides, is also associated with gene expression and cancer progression [84]. Among them, HOX transcript antisense RNA (HOTAIR) [84], metastasis-associated lung adenocarcinoma transcript 1 (MALAT1) [85] and lncRNA H1 [86] are predictors of poor survival in OSCC.

miR-126 is an endothelial, cell-specific miRNA located in intron 7 of epidermal growth factor-like domain 7 (EGFL7), and its overexpression promotes vessel formation by repressing expression of sprouty-related protein-1 (Spred-1) in developmental angiogenesis [6,87]. Previously, we reported 
that miR-126 and its host gene, EGFL7, were downregulated by DNA hypermethylation in OSCC cells [88]. In addition, miR-126 is a negative regulator of VEGF-A activation and promotes tumor cell growth in OSCC cells. In human OSCC specimens, a low miR-126 expression was observed in 94 of 118 cases $(79.7 \%)$ and was relevant to local tumor expansion (T grade), clinical stage, and nodal metastasis. Besides, the reduced miR-126 expression correlated with tumor angiogenesis and lymphangiogenesis and poorer outcomes. Furthermore, multivariate analysis revealed that miR-126 expression levels were independent prognostic factors for disease-free survival periods in OSCC.

Table 1. Functional roles of novel prognosticators of oral squamous cell carcinoma (OSCC).

\begin{tabular}{|c|c|c|c|}
\hline Factors & Behavior & Role on the Hallmarks of Cancer & References \\
\hline TANGO & Upregulated & $\begin{array}{l}\text { Sustaining proliferative signaling } \\
\text { Activating invasion and metastasis } \\
\text { Inducing angiogenesis } \\
\text { Resisting cell death }\end{array}$ & [46] \\
\hline ME1 & Upregulated & $\begin{array}{l}\text { Sustaining proliferative signaling } \\
\text { Activating invasion and metastasis } \\
\text { Deregulating energetics }\end{array}$ & [58] \\
\hline $\operatorname{miR}-126$ & Downregulated & $\begin{array}{l}\text { Sustaining proliferative signaling } \\
\text { Evading growth suppressors } \\
\text { Inducing angiogenesis }\end{array}$ & [68] \\
\hline FOXC2 & Upregulated & Inducing angiogenesis & [75] \\
\hline PROX1 & Upregulated & $\begin{array}{l}\text { Sustaining proliferative signaling } \\
\text { Activating invasion and metastasis } \\
\text { Inducing angiogenesis }\end{array}$ & [75] \\
\hline \multirow{2}{*}{$\mathrm{HuD}$} & \multirow{2}{*}{ Upregulated } & Activating invasion and metastasis & \multirow{2}{*}{ [89] } \\
\hline & & Resisting cell death & \\
\hline STOX2 & Upregulated & $\begin{array}{l}\text { Sustaining proliferative signaling } \\
\text { Avoiding immune destruction } \\
\text { Activating invasion and metastasis } \\
\text { Resisting cell death }\end{array}$ & [90] \\
\hline N4BP2L1 & Upregulated & Activating invasion and metastasis & [91] \\
\hline \multirow{2}{*}{ ZFAND4 } & \multirow{2}{*}{ Upregulated } & Activating invasion and metastasis & \multirow{2}{*}{ [92] } \\
\hline & & Inducing angiogenesis & \\
\hline NIPAL1 & Upregulated & Inducing angiogenesis & [93] \\
\hline \multirow{2}{*}{ LEMD1 } & \multirow{2}{*}{ Upregulated } & Activating invasion and metastasis & \multirow{2}{*}{ [94] } \\
\hline & & Inducing angiogenesis & \\
\hline PAUF & Upregulated & $\begin{array}{l}\text { Sustaining proliferative signaling } \\
\text { Activating invasion and metastasis } \\
\text { Inducing angiogenesis } \\
\text { Resisting cell death }\end{array}$ & [95] \\
\hline ME1 & upregulated & $\begin{array}{l}\text { sustaining proliferative signaling } \\
\text { activating invasion and metastasis } \\
\text { deregulating energetics }\end{array}$ & [58] \\
\hline
\end{tabular}

TANGO: transport and Golgi organization protein 1; ME1: malic enzyme 1; FOXC2: forkhead box protein C2; PROX1: prospero homeobox 1; HuD: Hu antigen D; STOX2: Storkhead box protein 2; N4BP2L1: NEDD4-binding protein 2-like 1; ZFAND4: zinc finger AN1-type containing 4; NIPL1: NIPA-like domain containing 1; LEMD1: LEM domain containing 1; PAUF: pancreatic adenocarcinoma upregulated factor.

\subsection{FOXC2}

Forkhead box protein C2 (FOXC2) is a transcriptional regulatory factor which is essential to cardiovascular development, including vascular endothelial cell differentiation and lymphatic vessel 
formation [96]. Reportedly, FOXC2 is a tumor-progressive factor in various malignancies and is closely associated with metastasis and prognosis [97-99]. In addition, FOXC2 regulated EMT and the gain of multiple anticancer drug resistance in cancer cells $[89,100]$. In OSCC, immunostaining for FOXC2 was observed in $23.3 \%$ (38/163) of cases and markedly related to MVD [101]. In addition, cases with FOXC2-positive OSCC exhibited markedly poorer prognosis than those with FOXC2-negative OSCC. In the functional analysis under a coculture of human OSCC cells and vascular endothelial cells, FOXC2 promoted angiogenesis by enhancing VEGF-A expression. Furthermore, FOXC2 regulated the gene expression of prospero homeobox 1 (PROX1) in OSCC cells. Our results suggested that FOXC2 could be a novel angiogenic inducer in OSCC cells.

\subsection{PROX1}

PROX1 is a nuclear transcription factor associated with the embryonic development of multiple organs, including the central nervous system, heart, lymphatic system, skeletal muscles, lens, retina, and so on [102]. Reportedly, PROX1 plays various tumor-dependent functional roles, which reflect both the oncogenic potential and a tumor-suppressive role [90]. In addition, PROX1 promoted cell growth, angiogenesis, and sorafenib resistance in patients with HCC [91,102] and is associated with the lymphangiogenesis, metastasis, and poor prognosis in various malignancies [92,103,104]. However, high PROX1 expression is related to better prognosis for pancreatic and gastric cancer patients $[105,106]$. Thus, PROX1's role in malignancies remains debatable. The PROX1 expression was found in $25.8 \%(42 / 163)$ of patients with OSCC by immunohistochemistry and was markedly associated with the local progression of the tumor (T classification), clinical stage, LVD, nodal metastasis, and expression levels of FOXC2 [101]. Besides, the survival and multivariate analysis revealed that PROX1 expression correlated with poor survival of OSCC patients. PROX1 also accelerated cell growth and lymphangiogeneis through VEGF-C activation in OSCC cells. Our findings indicated that PROX1 exhibits tumor-progressive function in OSCC. However, reportedly, the PROX1 reduction promoted OSCC cell proliferation [107]. Hence, further studies are warranted to elucidate the detailed molecular mechanisms underlying PROX1 in OSCC.

\subsection{TANGO}

Reportedly, MIA and MIA2 are involved in OSCC tumor progression [27,52]. The expression of the MIA gene family members is reported in several malignancies [93]. Transport and Golgi organization protein 1 (TANGO) is one of the MIA gene family members and comprises a highly conserved Src homology 3 (SH3)-like domain [4]. TANGO could be a suppressor of the invasion and migration of malignant melanoma, colorectal cancer (CRC), and HCC [108,109]. However, the TANGO expression reportedly correlated with tumor progression, nodal and distant metastasis, and shortened disease-free survival in SCC of the esophagus, lung, and uterine cervix [93]. In OSCC, TANGO also regulated adhesion to OSCC cells, transendothelial migration, and tube formation of vascular and lymphatic vascular endothelial cells by activating the platelet-derived growth factor- $\beta$ polypeptide (PDGFB) and neuropilin 2 [4,54]. Imatinib, an inhibitor of the PDGF receptor tyrosine kinase, might be useful for OSCC treatment because of decreased TANGO activity [4]. In addition, TANGO promoted migration and invasion while inhibiting apoptosis in human OSCC cells. We observed the TANGO expression in $35.1 \%(60 / 171)$ of OSCC specimens, markedly correlating with age, tumor progression (T grade) clinical stage, nodal metastasis, MVD, and LVD. Moreover, survival analysis elucidated markedly shorter disease-free survival periods in patients with the TANGO expression than in those without the TANGO expression. As the MIA gene family members are also secretory proteins [110], TANGO might be useful as a tumor marker detectable in the serum, saliva, urine, ascites and pleural fluid, and other samples [4,93]. Our findings suggested that TANGO exhibits tumor-progressive function in its activation of angiogenesis and lymphangiogenesis in OSCC. 


\section{5. $H u D$}

$\mathrm{Hu}$ antigen $\mathrm{D}(\mathrm{HuD})$ serves as an RNA-binding protein involved in mRNA stability and translational modulation. It contains an Au-rich element present in $3^{\prime}$-UTR and neuronal differentiation [94]. The leading target mRNAs of $\mathrm{HuD}$ are growth-associated protein 43 (GAP43), acetylcholine transferase (AchE), p21, c-myc, N-myc, Notch3, VEGF-A, and so on [111]. Previously, $\mathrm{HuD}$ expression has been reported in small cell lung carcinoma and neuroblastoma [112,113]. In addition, we previously reported that $\mathrm{HuD}$ regulated the invasion ability and activation of caspase-3, and the main target genes in OSCC cells of $\mathrm{HuD}$ are VEGF-A, VEGF-D, MMP-2, and $M M P-9$ [114]. In OSCC specimens, HuD expression was detected in $36.6 \%$ (30/82), and its expression closely correlated with the histological differentiation of the tumor, nodal metastasis, and diffuse invasion pattern. Moreover, a survival curve analysis revealed markedly worse outcomes in patients with the $\mathrm{HuD}$ expression than patients who were HuD-negative, and the HuD expression was an independent prognostic predictor in patients with OSCC. Besides, HuD is a useful diagnostic and therapeutic target in OSCC. As MMP-2 and -9 are components of the epithelial basement membrane and extracellular matrix proteins, HuD could be a novel modulator for the tumor microenvironmental modification in OSCC [114]. Furthermore, our results suggested that HuD is newly detected target of VEGF-A-mediated angiogenesis in OSCC.

\subsection{STOX2}

Storkhead box protein 2 (STOX2) is considered a transcriptional factor, and its expression is decreased in the decidual tissue of patients with fetal growth restriction [115]. A prior cDNA microarray analysis revealed that STOX2 expression is related to prognosis in CRC [116]. Conversely, a study reported that STOX2 expression levels in CRC were decreased by $\mathrm{CpG}$ island hypermethylation of the STOX2 promoter region [95]. Hence, the role of STOX2 in malignancies remains unclear. In OSCC cells, STOX2 expression levels were increased by MIA, secretory protein of melanoma, in a paracrine manner [117]. In addition, STOX2 modulated the cell growth, invasion, and inhibition of apoptosis in OSCC cells by interacting with MIA. Moreover, STOX2 promoted resistance to paclitaxel, cisplatin, and 5-FU in OSCC. In fact, immunostaining of STOX2 was observed in $28.7 \%$ (58/202) of OSCC cases and associated with nodal metastasis, MIA expression, and poor survival. Multivariate analysis revealed that STOX2 expression was an independent predictor of disease-free survival in OSCC patients. Interestingly, STOX2 expression was also observed in the stromal plasma cells surrounding OSCC. Although further studies are warranted to validate STOX2's role in the tumor stroma, it might contribute to the disruption of the host immune system. Hence, the MIA-STOX2 pathway might be a useful molecular target in OSCC.

\subsection{N4BP2L1}

Previously, we compared the gene expression profiles of primary and recurrent OSCC using cDNA microarray analysis, and the most increased level of expression in recurrent OSCC was NEDD4-binding protein 2-like 1 (N4BP2L1) [118]. Although N4BP2L1 is a critical paralog of N4BP2, highly expressed in nasopharyngeal carcinoma [119], little information was available about the functional role of N4BP2L1 in tumor cells. We determined that N4BP2L1 enhances invasion ability and miR-448 inversely regulates N4BP2L1 expression in OSCC cells [118]. In addition, the N4BP2L1 expression was observed in 34.8\% $(65 / 187)$ of OSCC cases by immunohistochemistry, and a marked correlation was observed between the N4BP2L1 expression and nodal metastasis. A gene expression analysis of 45 OSCC samples indicated lower miR-448 expression levels were conversely associated with N4BP2L1 upregulation. Moreover, the N4BP2L1 overexpression correlated with poor outcome and was an independent predictor of disease-free survival in OSCC patients. Hence, N4BP2L1 could be a new target for diagnosis and treatment of OSCC. 


\subsection{ZFAND4}

Zinc finger AN1-type containing 4 (ZFAND4) is one of the most upregulated genes in recurrent OSCC samples [118]. Although higher ZFAND4 expression, regulated by miR-182, strongly correlated with clinical stage progression in gastric cancer [120], little information is available about the functional roles of ZFAND4 in malignancies. Accordingly, we assessed the immunostaining of ZFAND4 in 214 OSCC cases [121]. The cytoplasmic expression of ZFAND4 was detected in 21\% $(45 / 214)$ of OSCC cases, and there appears to be a link between ZFAND4 expression and lymph node metastasis, lymphatic invasion, vascular infiltration, and poorer outcome. In addition, the ZFAND4 overexpression was considered an independent predictor of unfavorable prognosis in OSCC cases as revealed by a multivariate analysis. Intriguingly, high ZFAND4 expression was also implicated in distant OSCC metastasis. While 3.8-12.6\% OSCC patients experience metastasis, the disease becomes highly lethal when metastasis occurs [121,122]. Hence, ZFAND4 could be an essential molecular marker and therapeutic target for distant metastasis and prognosis of OSCC cells.

\subsection{NIPAL1}

Previously, we identified NIPA-like domain containing 1 (NIPAL1) as an overexpressed gene in recurrent OSCC [118]. NIPAL1 is a membranous magnesium transporter and has been associated with the pathogenesis of gout and hyperuricemia by indirect urate transport regulation [123]. Research has demonstrated that hyperuricemia is associated with an increased risk of cancer [124]. However, little is known about the NIPAL1's role in malignancies. In OSCC cells, NIPAL1 accelerated cancer cell proliferation and adhesion to vascular endothelial cells (intravasation) [125]. However, NIPAL1 failed to affect the transendothelial migration, tube formation, and branching of endothelial cells. Perhaps NIPAL1 might merely accelerate OSCC cell infiltration that had been evoked by other angiogenic factors. The NIPAL1 expression was detected in 20.3\% (39/192) of OSCC cases and correlated strongly with vascular invasion and short disease-free survival. Furthermore, the NIPAL1 expression was an independent predictor of poor prognosis in OSCC patients.

\subsection{LEMD1}

LEM domain containing 1 (LEMD1) comprises several splicing variants, and LEMD1 variant 1 (V1), V2, and V3 are cancer-testis antigens (CTA) [126]. Reportedly, LEMD1 overexpression has been detected in colon cancer, prostate cancer, and anaplastic large-cell lymphoma [126-128]. In addition, immunostaining for LEMD1 has been reported in 35\% (101/289) of OSCC specimens and closely involved in local progression ( $T$ factor), clinical stage, and nodal metastasis [129]. The disease-free survival among all LEMD1-positive patients was considerably worse compared to LEMD1-negative patients, and the LEMD1 expression was an independent prognosticator. In an in vitro analysis using OSCC cells, LEMD1 enhanced invasion ability. Moreover, we determined that LEMD1 controlled the intravasation and transmigration of OSCC cells to endothelial cells. Since CTA in cancer is a useful target of immunotherapy through the activation of CTL [130], LEMD1 normalization might be useful for activating the host immune function of OSCC. Perhaps, LEMD1 might be a novel tumor-promoting and prognostic CTA that induces the gain of invasion ability and transendothelial migration of OSCC.

\subsection{PAUF}

Pancreatic adenocarcinoma upregulated factor (PAUF) is a newly determined secretory protein in pancreatic cancer [131]. PAUF is a ligand for toll-like receptor 2 (TLR2) and TLR4 and can promote the migration, invasion, proliferation, angiogenesis, and CXC receptor type 4 (CXCR4)-mediated metastasis of pancreatic cancer cells [131-134]. In addition, PAUF contributes to the insufficiency of T-cell immunosurveillance and immunoescape through the migration and activation of myeloid-derived immature cells in pancreatic cancer [135]. Moreover, PAUF has been reported to decrease pancreatic cancer cells' sensitivity to gemcitabine and 5-FU [134]. Recently, we reported 
that PAUF facilitated growth, invasion, suppression of apoptosis, and cisplatin resistance in OSCC cells [136]. In an immunohistochemical analysis, PAUF expression was detected in $23.4 \%(52 / 222)$ of OSCC cases, and the immunoreactivity for PAUF markedly correlated with nodal metastasis. We also revealed that PAUF-positive patients exhibited a remarkably shorter disease-free and overall survival than PAUF-negative patients. Furthermore, a multivariate analysis revealed that PAUF expression was an independent prognostic predictor of poor disease-free survival and cancer-specific mortality of OSCC patients. Thus, our findings indicate that PAUF is a useful molecular target for OSCC diagnosis and therapy.

\subsection{ME1}

Malic enzyme 1 (ME1) is a multifunctional protein involved in glycolysis, the citric acid cycle, NADPH production, glutamine metabolism, and lipogenesis [137]. In malignancies, ME1 overexpression correlated with unfavorable prognosis in HCC patients by EMT induction [137]. In addition, ME1 is associated with tumor growth, lung metastasis, peritoneal dissemination, and shorter overall and disease-free survival in gastric cancer cases [138]. Our experimental data suggested that ME1 promotes cancer progression by increasing lactate fermentation, maintaining redox status, acquiring stemness and EMT phenotype, and promoting tumor growth and invasion in OSCC cells [74]. In addition, ME1 expression closely correlated with local progression ( $T$ factor), clinical stage, and nodal metastasis in human OSCC specimens. Furthermore, the survival analysis using the Kaplan-Meier method revealed that cases with moderate-to-strong ME1 expression exhibited markedly worse prognosis than those with weak ME1 expression. Since inhibiting ME1 suppressed tumor growth and increased survival time in a mouse tumor model, ME1 could be a valid target for molecular therapy in OSCC.

\section{Conclusions}

Initially, Hanahan and Weinberg proposed six hallmarks of the cancer cell model: sustained proliferative signals, evasion of growth suppressors, resistance to cell death, replicative immortality, induction of angiogenesis, and activation of invasion and metastasis $[6,139]$. Considering the dramatic progress in modern cancer research, they added two emerging hallmarks-avoidance of immune destruction and deregulation of cellular energetics-and two enabling characteristics-genome instability and mutation and tumor-promoting inflammation-in $2011[5,6]$. Although advances in molecular oncological biology have elucidated OSCC molecular mechanisms, the prognosis of locoregionally and metastatically advanced cancer awaits improvement. Several studies about invasion, metastasis, and prognosis-related molecular biomarkers for malignancies, including OSCC, have been published to date. Recently, molecular-targeted therapy using cetuximab, an anti-EGFR-specific chimeric monoclonal antibody, and nivolumab, an antibody inhibitor of PD-1 receptor, is used in OSCC patients [140,141]. However, other targets for diagnosis and treatment of OSCC remain unknown, necessitating the development of useful molecular tumor markers. Hopefully, relevant novel tumor biomarkers will be established in the near future.

Author Contributions: Design and drafting, T.S.; Writing and revision, T.K.

Funding: This work was supported in part by the Grant-in-Aid for Scientific Research from the Japan Society for the Promotion of Science, Japan.

Acknowledgments: We would like to give special thanks to Miyako Kurihara-Shimomura, Yukiko Nishiguchi, Chie Nakashima, and Hiroyuki Shimomura for their helpful support.

Conflicts of Interest: The authors declare no conflict of interest. 


\section{Abbreviations}

\begin{tabular}{|c|c|}
\hline 5-Aza-dc & 5-aza-2'-deoxycytidine \\
\hline 5 -FU & 5-fluorouracil \\
\hline AchE & acetylcholine transferase \\
\hline ATP & adenosine triphosphate \\
\hline Bak & Bcl-2 homologous antagonist killer \\
\hline Bax & Bcl-2-associated X protein \\
\hline Bcl-2 & B-cell lymphoma-2 \\
\hline COX-2 & cyclooxygenase-2 \\
\hline CRC & colorectal cancer \\
\hline CTL & cytotoxic T cells \\
\hline CXCL9 & chemokine (C-X-C motif) ligand 9 \\
\hline CXCR4 & CXC receptor type 4 \\
\hline DCRG8 & Drosha and DiGeorge syndrome critical region gene 8 \\
\hline EGF & epidermal growth factor \\
\hline EGFL7 & epidermal growth factor-like domain 7 \\
\hline EGFR & epidermal growth factor receptor \\
\hline EMT & epithelial-mesenchymal transition \\
\hline FasL & Fas ligand \\
\hline FDG-PET & {$\left[{ }^{18}\right.$ F]fluoro-2-deoxyglucose-positron emission tomography } \\
\hline FOXC2 & Forkhead box protein $\mathrm{C} 2$ \\
\hline GAP43 & growth-associated protein 43 \\
\hline GLUT-1 & glucose transporter 1 \\
\hline HER1 & human epidermal growth factor receptor 1 \\
\hline HIF1- $\alpha$ & hypoxia-inducible factor $1 \mathrm{a}$ \\
\hline hTERT & human telomerase reverse transcriptase \\
\hline $\mathrm{HuD}$ & Hu antigen D \\
\hline IL & interleukin \\
\hline IRS-1 & insulin receptor substrate 1 \\
\hline LEMD1 & LEM domain containing 1 \\
\hline $\mathrm{LOH}$ & loss of heterozygosity \\
\hline MAPK & mitogen-activated protein kinase \\
\hline ME1 & malic enzyme 1 \\
\hline MIA2 & melanoma inhibitory activity 2 \\
\hline miRNAs & microRNAs \\
\hline MMP & matrix metalloproteinase matrix \\
\hline mTOR & mammalian target of rapamycin \\
\hline N4BP2L1 & NEDD4-binding protein 2-like 1 \\
\hline NIPAL1 & NIPA-like domain containing 1 \\
\hline NK & natural killer \\
\hline OSCC & oral squamous cell carcinoma \\
\hline PAUF & pancreatic adenocarcinoma upregulated factor \\
\hline PD-1 & programmed cell death 1 \\
\hline PDGF & platelet-derived growth factor \\
\hline PDGFB & platelet-derived growth factor- $\beta$ polypeptide \\
\hline pEGFR & phosphorylated EGFR \\
\hline PI3K & phosphoinositide 3-kinase \\
\hline POT1 & protection of telomeres \\
\hline pre-miRNA & precursor miRNA \\
\hline pri-miRNA & primary miRNA \\
\hline PROX1 & prospero homeobox 1 \\
\hline
\end{tabular}




$\begin{array}{ll}\text { pSTAT3 } & \text { phosphorylated STAT3 } \\ \text { PTEN } & \text { phosphatase and tensin homolog } \\ \text { RAP1 } & \text { repressor activator protein 1 } \\ \text { RISC } & \text { RNA-induced silencing complex } \\ \text { SH3 } & \text { Src homology } 3 \\ \text { SIS } & \text { systemic inflammatory score } \\ \text { Spred-1 } & \text { sprouty-related protein-1 } \\ \text { STAT } & \text { signal transducer and activator of transcription } \\ \text { STOX2 } & \text { Storkhead box protein 2 } \\ \text { TANGO } & \text { Transport and Golgi organization protein 1 } \\ \text { TGF- } \beta & \text { transforming growth factor- } \beta \\ \text { Th1 cells } & \text { T helper type 1 cells } \\ \text { TIN2 } & \text { TRF1-interacting nuclear factor 2 } \\ \text { TLR2 } & \text { toll-like receptor 2 } \\ \text { TNF } \alpha & \text { tumor necrosis factor- } \alpha \\ \text { TPP1 } & \text { POT1-interacting protein } \\ \text { TRAIL } & \text { TNF-related apoptosis-inducing ligand } \\ \text { Treg } & \text { T regulatory } \\ \text { TRF } & \text { telomeric repeat factor } \\ \text { UTR } & \text { untranslated region } \\ \text { VEGF } & \text { vascular endothelial growth factor } \\ \text { ZFAND4 } & \text { zinc finger AN1-type containing } 4 \\ & \end{array}$

\section{References}

1. Torre, L.A.; Bray, F.; Siegel, R.L.; Ferlay, J.; Lortet-Tieulent, J.; Jemal, A. Global cancer statistics, 2012. CA Cancer J. Clin. 2015, 65, 87-108. [CrossRef] [PubMed]

2. Kim, J.W.; Park, Y.; Roh, J.L.; Cho, K.J.; Choi, S.H.; Nam, S.Y.; Kim, S.Y. Prognostic value of glucosylceramide synthase and P-glycoprotein expression in oral cavity cancer. Int. J. Clin. Oncol. 2016, 21, 883-889. [CrossRef] [PubMed]

3. Gonzalez-Garcia, R.; Naval-Gias, L.; Rodriguez-Campo, F.J.; Sastre-Perez, J.; Munoz-Guerra, M.F.; Gil-Diez Usandizaga, J.L. Contralateral lymph neck node metastasis of squamous cell carcinoma of the oral cavity: a retrospective analytic study in 315 patients. J. Oral Maxillofac. Surg. 2008, 66, 1390-1398. [CrossRef] [PubMed]

4. Sasahira, T.; Bosserhoff, A.K.; Kirita, T. The importance of melanoma inhibitory activity gene family in the tumor progression of oral cancer. Pathol. Int. 2018, 68, 278-286. [CrossRef] [PubMed]

5. Hanahan, D.; Weinberg, R.A. Hallmarks of cancer: The next generation. Cell 2011, 144, 646-674. [CrossRef] [PubMed]

6. Sasahira, T.; Kuniyasu, H. Molecular Biology of the Oral Cancer. In Oral Cancer Diagnosis and Therapy; Kirita, T., Omura, K., Eds.; Springer: Tokyo, Japan, 2015; pp. 63-82.

7. Bernardes, V.F.; Gleber-Netto, F.O.; Sousa, S.F.; Silva, T.A.; Aguiar, M.C. Clinical significance of EGFR, Her-2 and EGF in oral squamous cell carcinoma: A case control study. J. Exp. Clin. Cancer Res. 2010, $29,40$. [CrossRef] [PubMed]

8. Silva, S.D.; Perez, D.E.; Alves, F.A.; Nishimoto, I.N.; Pinto, C.A.; Kowalski, L.P.; Graner, E. ErbB2 and fatty acid synthase (FAS) expression in 102 squamous cell carcinomas of the tongue: Correlation with clinical outcomes. Oral Oncol. 2008, 44, 484-490. [CrossRef] [PubMed]

9. Monteiro, L.; Ricardo, S.; Delgado, M.; Garcez, F.; do Amaral, B.; Lopes, C. Phosphorylated EGFR at tyrosine 1173 correlates with poor prognosis in oral squamous cell carcinomas. Oral Dis. 2014, 20, 178-185. [CrossRef] [PubMed]

10. Silva, S.D.; Alaoui-Jamali, M.A.; Hier, M.; Soares, F.A.; Graner, E.; Kowalski, L.P. Cooverexpression of ERBB1 and ERBB4 receptors predicts poor clinical outcome in $\mathrm{pN}+$ oral squamous cell carcinoma with extranodal spread. Clin. Exp. Metastasis 2014, 31, 307-316. [CrossRef] [PubMed]

11. Miyamoto, R.; Uzawa, N.; Nagaoka, S.; Hirata, Y.; Amagasa, T. Prognostic significance of cyclin D1 amplification and overexpression in oral squamous cell carcinomas. Oral Oncol. 2003, 39, 610-618. [CrossRef] 
12. Lim, Y.C.; Han, J.H.; Kang, H.J.; Kim, Y.S.; Lee, B.H.; Choi, E.C.; Kim, C.H. Overexpression of c-Met promotes invasion and metastasis of small oral tongue carcinoma. Oral Oncol. 2012, 48, 1114-1149. [CrossRef] [PubMed]

13. Macha, M.A.; Matta, A.; Kaur, J.; Chauhan, S.S.; Thakar, A.; Shukla, N.K.; Gupta, S.D.; Ralhan, R. Prognostic significance of nuclear pSTAT3 in oral cancer. Head Neck 2011, 33, 482-489. [CrossRef] [PubMed]

14. Klosek, S.K.; Nakashiro, K.; Hara, S.; Li, C.; Shintani, S.; Hamakawa, H. Constitutive activation of Stat3 correlates with increased expression of the c-Met/HGF receptor in oral squamous cell carcinoma. Oncol. Rep. 2004, 12, 293-296. [CrossRef] [PubMed]

15. Choi, S.; Myers, J.N. Molecular pathogenesis of oral squamous cell carcinoma: Implications for therapy. J. Dent. Res. 2008, 87, 14-32. [CrossRef] [PubMed]

16. Network, C.G.A. Comprehensive genomic characterization of head and neck squamous cell carcinomas. Nature 2015, 517, 576-582. [CrossRef] [PubMed]

17. Neskey, D.M.; Osman, A.A.; Ow, T.J.; Katsonis, P.; McDonald, T.; Hicks, S.C.; Hsu, T.K.; Pickering, C.R.; Ward, A.; Patel, A.; et al. Evolutionary Action Score of TP53 Identifies High-Risk Mutations Associated with Decreased Survival and Increased Distant Metastases in Head and Neck Cancer. Cancer Res. 2015, 75, 1527-1536. [CrossRef] [PubMed]

18. Osman, A.A.; Neskey, D.M.; Katsonis, P.; Patel, A.A.; Ward, A.M.; Hsu, T.K.; Hicks, S.C.; McDonald, T.O.; Ow, T.J.; Alves, M.O.; et al. Evolutionary Action Score of TP53 Coding Variants Is Predictive of Platinum Response in Head and Neck Cancer Patients. Cancer Res. 2015, 75, 1205-1215. [CrossRef] [PubMed]

19. Sandulache, V.C.; Michikawa, C.; Kataria, P.; Gleber-Netto, F.O.; Bell, D.; Trivedi, S.; Rao, X.; Wang, J.; Zhao, M.; Jasser, S.; et al. High-Risk TP53 Mutations Are Associated with Extranodal Extension in Oral Cavity Squamous Cell Carcinoma. Clin. Cancer Res. 2018, 24, 1727-1733. [CrossRef] [PubMed]

20. De Oliveira, L.R.; Ribeiro-Silva, A.; Zucoloto, S. Prognostic impact of p53 and p63 immunoexpression in oral squamous cell carcinoma. J. Oral Pathol. Med. 2007, 36, 191-197. [CrossRef] [PubMed]

21. Zhang, M.; Li, J.; Wang, L.; Tian, Z.; Zhang, P.; Xu, Q.; Zhang, C.; Wei, F.; Chen, W. Prognostic significance of p21, p27 and survivin protein expression in patients with oral squamous cell carcinoma. Oncol. Lett. 2013, 6, 381-386. [CrossRef] [PubMed]

22. Padhi, S.S.; Roy, S.; Kar, M.; Saha, A.; Roy, S.; Adhya, A.; Baisakh, M.; Banerjee, B. Role of CDKN2A/p16 expression in the prognostication of oral squamous cell carcinoma. Oral Oncol. 2017, 73, 27-35. [CrossRef] [PubMed]

23. Khalid, A.; Hussain, T.; Manzoor, S.; Saalim, M.; Khaliq, S. PTEN: A potential prognostic marker in virus-induced hepatocellular carcinoma. Tumour Biol. 2017, 39, 1010428317705754. [CrossRef] [PubMed]

24. Zhao, J.; Chi, J.; Gao, M.; Zhi, J.; Li, Y.; Zheng, X. Loss of PTEN Expression Is Associated With High MicroRNA 24 Level and Poor Prognosis in Patients With Tongue Squamous Cell Carcinoma. J. Oral Maxillofac. Surg. 2017, 75, 1449.e1-1449.e8. [CrossRef] [PubMed]

25. Kurasawa, Y.; Shiiba, M.; Nakamura, M.; Fushimi, K.; Ishigami, T.; Bukawa, H.; Yokoe, H.; Uzawa, K.; Tanzawa, H. PTEN expression and methylation status in oral squamous cell carcinoma. Oncol. Rep. 2008, 19, 1429-1434. [PubMed]

26. Panda, S.; Padhiary, S.K.; Routray, S. Chemokines accentuating protumoral activities in oral cancer microenvironment possess an imperious stratagem for therapeutic resolutions. Oral Oncol. 2016, 60, 8-17. [CrossRef] [PubMed]

27. Kurihara, M.; Kirita, T.; Sasahira, T.; Ohmori, H.; Matsushima, S.; Yamamoto, K.; Bosserhoff, A.K.; Kuniyasu, H. Protumoral roles of melanoma inhibitory activity 2 in oral squamous cell carcinoma. Br. J. Cancer 2013, 108, 1460-1469. [CrossRef] [PubMed]

28. Chang, K.P.; Wu, C.C.; Fang, K.H.; Tsai, C.Y.; Chang, Y.L.; Liu, S.C.; Kao, H.K. Serum levels of chemokine (C-X-C motif) ligand 9 (CXCL9) are associated with tumor progression and treatment outcome in patients with oral cavity squamous cell carcinoma. Oral Oncol. 2013, 49, 802-807. [CrossRef] [PubMed]

29. Fujita, Y.; Okamoto, M.; Goda, H.; Tano, T.; Nakashiro, K.; Sugita, A.; Fujita, T.; Koido, S.; Homma, S.; Kawakami, Y.; et al. Prognostic significance of interleukin-8 and CD163-positive cell-infiltration in tumor tissues in patients with oral squamous cell carcinoma. PLoS ONE 2014, 9, e110378. [CrossRef] [PubMed]

30. He, J.; Hu, Y.; Hu, M.; Li, B. Development of PD-1/PD-L1 Pathway in Tumor Immune Microenvironment and Treatment for Non-Small Cell Lung Cancer. Sci. Rep. 2015, 5, 13110. [CrossRef] [PubMed] 
31. Ohaegbulam, K.C.; Assal, A.; Lazar-Molnar, E.; Yao, Y.; Zang, X. Human cancer immunotherapy with antibodies to the PD-1 and PD-L1 pathway. Trends Mol. Med. 2015, 21, 24-33. [CrossRef] [PubMed]

32. Lipson, E.J.; Forde, P.M.; Hammers, H.J.; Emens, L.A.; Taube, J.M.; Topalian, S.L. Antagonists of PD-1 and PD-L1 in Cancer Treatment. Semin. Oncol. 2015, 42, 587-600. [CrossRef] [PubMed]

33. Maruse, Y.; Kawano, S.; Jinno, T.; Matsubara, R.; Goto, Y.; Kaneko, N.; Sakamoto, T.; Hashiguchi, Y.; Moriyama, M.; Toyoshima, T.; et al. Significant association of increased PD-L1 and PD-1 expression with nodal metastasis and a poor prognosis in oral squamous cell carcinoma. Int. J. Oral Maxillofac. Surg. 2018, 47, 836-845. [CrossRef] [PubMed]

34. Luo, S.L.; Xie, Y.G.; Li, Z.; Ma, J.H.; Xu, X. E-cadherin expression and prognosis of oral cancer: A meta-analysis. Tumour Biol. 2014, 35, 5533-5537. [CrossRef] [PubMed]

35. Li, H.X.; Zheng, J.H.; Fan, H.X.; Li, H.P.; Gao, Z.X.; Chen, D. Expression of $\alpha v \beta 6$ integrin and collagen fibre in oral squamous cell carcinoma: Association with clinical outcomes and prognostic implications. J. Oral Pathol. Med. 2013, 42, 547-556. [CrossRef] [PubMed]

36. Ming, X.Y.; Fu, L.; Zhang, L.Y.; Qin, Y.R.; Cao, T.T.; Chan, K.W.; Ma, S.; Xie, D.; Guan, X.Y. Integrin $\alpha 7$ is a functional cancer stem cell surface marker in oesophageal squamous cell carcinoma. Nat. Commun. 2016, 7, 13568. [CrossRef] [PubMed]

37. Pu, Y.; Wang, L.; Wu, H.; Feng, Z.; Wang, Y.; Guo, C. High MMP-21 expression in metastatic lymph nodes predicts unfavorable overall survival for oral squamous cell carcinoma patients with lymphatic metastasis. Oncol. Rep. 2014, 31, 2644-2650. [CrossRef] [PubMed]

38. Vincent-Chong, V.K.; Salahshourifar, I.; Karen-Ng, L.P.; Siow, M.Y.; Kallarakkal, T.G.; Ramanathan, A.; Yang, Y.H.; Khor, G.H.; Rahman, Z.A.; Ismail, S.M.; et al. Overexpression of MMP13 is associated with clinical outcomes and poor prognosis in oral squamous cell carcinoma. Sci. World J. 2014, 2014, 897523. [CrossRef] [PubMed]

39. Jiang, T.; Xie, P.; Liu, H. Circulating Anti-Matrix Metalloproteinase-7 Antibodies May Be a Potential Biomarker for Oral Squamous Cell Carcinoma. J. Oral Maxillofac. Surg. 2016, 74, 650-657. [CrossRef] [PubMed]

40. Hsin, C.H.; Chou, Y.E.; Yang, S.F.; Su, S.C.; Chuang, Y.T.; Lin, S.H.; Lin, C.W. MMP-11 promoted the oral cancer migration and Fak/Src activation. Oncotarget 2017, 8, 32783-32793. [CrossRef] [PubMed]

41. Sasahira, T.; Kirita, T.; Kuniyasu, H. Update of molecular pathobiology in oral cancer: A review. Int. J. Clin. Oncol. 2014, 19, 431-436. [CrossRef] [PubMed]

42. Liu, S.; Liu, L.; Ye, W.; Ye, D.; Wang, T.; Guo, W.; Liao, Y.; Xu, D.; Song, H.; Zhang, L.; et al. High Vimentin Expression Associated with Lymph Node Metastasis and Predicated a Poor Prognosis in Oral Squamous Cell Carcinoma. Sci. Rep. 2016, 6, 38834. [CrossRef] [PubMed]

43. Eltohami, Y.I.; Kao, H.K.; Lao, W.W.; Huang, Y.; Abdelrahman, M.; Liao, C.T.; Yen, T.C.; Chang, K.P. The Prediction Value of the Systemic Inflammation Score for Oral Cavity Squamous Cell Carcinoma. Otolaryngol. Head Neck Surg. 2018, 158, 1042-1050. [CrossRef] [PubMed]

44. Kurihara, Y.; Hatori, M.; Ando, Y.; Ito, D.; Toyoshima, T.; Tanaka, M.; Shintani, S. Inhibition of cyclooxygenase-2 suppresses the invasiveness of oral squamous cell carcinoma cell lines via down-regulation of matrix metalloproteinase-2 production and activation. Clin. Exp. Metastasis 2009, 26, 425-432. [CrossRef] [PubMed]

45. Kono, M.; Watanabe, M.; Abukawa, H.; Hasegawa, O.; Satomi, T.; Chikazu, D. Cyclo-oxygenase-2 expression is associated with vascular endothelial growth factor $C$ expression and lymph node metastasis in oral squamous cell carcinoma. J. Oral Maxillofac. Surg. 2013, 71, 1694-1702. [CrossRef] [PubMed]

46. Jinno, T.; Kawano, S.; Maruse, Y.; Matsubara, R.; Goto, Y.; Sakamoto, T.; Hashiguchi, Y.; Kaneko, N.; Tanaka, H.; Kitamura, R.; et al. Increased expression of interleukin-6 predicts poor response to chemoradiotherapy and unfavorable prognosis in oral squamous cell carcinoma. Oncol. Rep. 2015, 33, 2161-2168. [CrossRef] [PubMed]

47. Benhamou, Y.; Picco, V.; Pages, G. The telomere proteins in tumorigenesis and clinical outcomes of oral squamous cell carcinoma. Oral Oncol. 2016, 57, 46-53. [CrossRef] [PubMed]

48. Zhao, T.; Hu, F.; Qiao, B.; Chen, Z.; Tao, Q. Telomerase reverse transcriptase potentially promotes the progression of oral squamous cell carcinoma through induction of epithelial-mesenchymal transition. Int. J. Oncol. 2015, 46, 2205-2215. [CrossRef] [PubMed] 
49. McCaul, J.A.; Gordon, K.E.; Minty, F.; Fleming, J.; Parkinson, E.K. Telomere dysfunction is related to the intrinsic radio-resistance of human oral cancer cells. Oral Oncol. 2008, 44, 261-269. [CrossRef] [PubMed]

50. Chen, H.H.; Yu, C.H.; Wang, J.T.; Liu, B.Y.; Wang, Y.P.; Sun, A.; Tsai, T.C.; Chiang, C.P. Expression of human telomerase reverse transcriptase (hTERT) protein is significantly associated with the progression, recurrence and prognosis of oral squamous cell carcinoma in Taiwan. Oral Oncol. 2007, 43, 122-129. [CrossRef] [PubMed]

51. Benhamou, Y.; Picco, V.; Raybaud, H.; Sudaka, A.; Chamorey, E.; Brolih, S.; Monteverde, M.; Merlano, M.; Lo Nigro, C.; Ambrosetti, D.; et al. Telomeric repeat-binding factor 2: A marker for survival and anti-EGFR efficacy in oral carcinoma. Oncotarget 2016, 7, 44236-44251. [CrossRef] [PubMed]

52. Sasahira, T.; Kirita, T.; Kurihara, M.; Yamamoto, K.; Bhawal, U.K.; Bosserhoff, A.K.; Kuniyasu, H. MIA-dependent angiogenesis and lymphangiogenesis are closely associated with progression, nodal metastasis and poor prognosis in tongue squamous cell carcinoma. Eur. J. Cancer 2010, 46, 2285-2294. [CrossRef] [PubMed]

53. Li, T.; Kang, G.; Wang, T.; Huang, H. Tumor angiogenesis and anti-angiogenic gene therapy for cancer. Oncol. Lett. 2018, 16, 687-702. [CrossRef] [PubMed]

54. Sasahira, T.; Kirita, T.; Yamamoto, K.; Ueda, N.; Kurihara, M.; Matsushima, S.; Bhawal, U.K.; Bosserhoff, A.K.; Kuniyasu, H. Transport and Golgi organisation protein 1 is a novel tumour progressive factor in oral squamous cell carcinoma. Eur. J. Cancer 2014, 50, 2142-2151. [CrossRef] [PubMed]

55. Yu, T.; Wang, Z.; Liu, K.; Wu, Y.; Fan, J.; Chen, J.; Li, C.; Zhu, G.; Li, L. High interstitial fluid pressure promotes tumor progression through inducing lymphatic metastasis-related protein expressions in oral squamous cell carcinoma. Clin. Transl. Oncol. 2014, 16, 539-547. [CrossRef] [PubMed]

56. Yanase, M.; Kato, K.; Yoshizawa, K.; Noguchi, N.; Kitahara, H.; Nakamura, H. Prognostic value of vascular endothelial growth factors A and C in oral squamous cell carcinoma. J. Oral Pathol. Med. 2014, 43, 514-520. [CrossRef] [PubMed]

57. Chen, C.; Zhang, Y.; Loomis, M.M.; Upton, M.P.; Lohavanichbutr, P.; Houck, J.R.; Doody, D.R.; Mendez, E.; Futran, N.; Schwartz, S.M.; et al. Genome-Wide Loss of Heterozygosity and DNA Copy Number Aberration in HPV-Negative Oral Squamous Cell Carcinoma and Their Associations with Disease-Specific Survival. PLoS ONE 2015, 10, e0135074. [CrossRef] [PubMed]

58. Salahshourifar, I.; Vincent-Chong, V.K.; Chang, H.Y.; Ser, H.L.; Ramanathan, A.; Kallarakkal, T.G.; Rahman, Z.A.; Ismail, S.M.; Prepageran, N.; Mustafa, W.M.; et al. Downregulation of CRNN gene and genomic instability at 1q21.3 in oral squamous cell carcinoma. Clin. Oral Investig. 2015, 19, 2273-2283. [CrossRef] [PubMed]

59. Basu, B.; Chakraborty, J.; Chandra, A.; Katarkar, A.; Baldevbhai, J.R.K.; Dhar Chowdhury, D.; Ray, J.G.; Chaudhuri, K.; Chatterjee, R. Genome-wide DNA methylation profile identified a unique set of differentially methylated immune genes in oral squamous cell carcinoma patients in India. Clin. Epigenet. 2017, 9, 13. [CrossRef] [PubMed]

60. Nishikawa, Y.; Miyazaki, T.; Nakashiro, K.; Yamagata, H.; Isokane, M.; Goda, H.; Tanaka, H.; Oka, R.; Hamakawa, H. Human FAT1 cadherin controls cell migration and invasion of oral squamous cell carcinoma through the localization of beta-catenin. Oncol. Rep. 2011, 26, 587-592. [PubMed]

61. Yu, C.C.; Hung, S.K.; Lin, H.Y.; Chiou, W.Y.; Lee, M.S.; Liao, H.F.; Huang, H.B.; Ho, H.C.; Su, Y.C. Targeting the $\mathrm{PI} 3 \mathrm{~K} / \mathrm{AKT} / \mathrm{mTOR}$ signaling pathway as an effectively radiosensitizing strategy for treating human oral squamous cell carcinoma in vitro and in vivo. Oncotarget 2017, 8, 68641-68653. [CrossRef] [PubMed]

62. Yoshida, R.; Ito, T.; Hassan, W.A.; Nakayama, H. Notch1 in oral squamous cell carcinoma. Histol. Histopathol. 2017, 32, 315-323. [PubMed]

63. Kalu, N.N.; Mazumdar, T.; Peng, S.; Tong, P.; Shen, L.; Wang, J.; Banerjee, U.; Myers, J.N.; Pickering, C.R.; Brunell, D.; et al. Comprehensive pharmacogenomic profiling of human papillomavirus-positive and -negative squamous cell carcinoma identifies sensitivity to aurora kinase inhibition in KMT2D mutants. Cancer Lett. 2018, 431, 64-72. [PubMed]

64. Bui, N.; Huang, J.K.; Bojorquez-Gomez, A.; Licon, K.; Sanchez, K.S.; Tang, S.N.; Beckett, A.N.; Wang, T.; Zhang, W.; Shen, J.P.; et al. Disruption of NSD1 in Head and Neck Cancer Promotes Favorable Chemotherapeutic Responses Linked to Hypomethylation. Mol. Cancer Ther. 2018, 17, 1585-1594. [PubMed] 
65. Murugan, A.K.; Hong, N.T.; Cuc, T.T.; Hung, N.C.; Munirajan, A.K.; Ikeda, M.A.; Tsuchida, N. Detection of two novel mutations and relatively high incidence of H-RAS mutations in Vietnamese oral cancer. Oral Oncol. 2009, 45. [CrossRef]

66. Pfeffer, C.M.; Singh, A.T.K. Apoptosis: A Target for Anticancer Therapy. Int. J. Mol. Sci. 2018, 19, 448.

67. Kato, K.; Kawashiri, S.; Yoshizawa, K.; Kitahara, H.; Yamamoto, E. Apoptosis-associated markers and clinical outcome in human oral squamous cell carcinomas. J. Oral Pathol. Med. 2008, 37, 364-371. [CrossRef] [PubMed]

68. Camisasca, D.R.; Honorato, J.; Bernardo, V.; da Silva, L.E.; da Fonseca, E.C.; de Faria, P.A.; Dias, F.L.; Lourenco Sde, Q. Expression of Bcl-2 family proteins and associated clinicopathologic factors predict survival outcome in patients with oral squamous cell carcinoma. Oral Oncol. 2009, 45, 225-233. [PubMed]

69. Xie, S.; Xu, H.; Shan, X.; Liu, B.; Wang, K.; Cai, Z. Clinicopathological and prognostic significance of survivin expression in patients with oral squamous cell carcinoma: Evidence from a meta-analysis. PLoS ONE 2015, 10, e0116517. [CrossRef] [PubMed]

70. Liu, S.; Shi, L.; Yang, X.; Ye, D.; Wang, T.; Dong, C.; Guo, W.; Liao, Y.; Song, H.; Xu, D.; et al. Nuclear survivin promoted by acetylation is associated with the aggressive phenotype of oral squamous cell carcinoma. Cell Cycle 2017, 16, 894-902. [PubMed]

71. Nagata, M.; Nakayama, H.; Tanaka, T.; Yoshida, R.; Yoshitake, Y.; Fukuma, D.; Kawahara, K.; Nakagawa, Y.; Ota, K.; Hiraki, A.; et al. Overexpression of cIAP2 contributes to 5-FU resistance and a poor prognosis in oral squamous cell carcinoma. Br. J. Cancer 2011, 105, 1322-1330. [CrossRef] [PubMed]

72. Warburg, O. On the origin of cancer cells. Science 1956, 123, 309-314. [CrossRef] [PubMed]

73. Lu, J.; Tan, M.; Cai, Q. The Warburg effect in tumor progression: Mitochondrial oxidative metabolism as an anti-metastasis mechanism. Cancer Lett. 2015, 356, 156-164. [CrossRef] [PubMed]

74. Nakashima, C.; Yamamoto, K.; Fujiwara-Tani, R.; Luo, Y.; Matsushima, S.; Fujii, K.; Ohmori, H.; Sasahira, T.; Sasaki, T.; Kitadai, Y.; et al. Expression of cytosolic malic enzyme (ME1) is associated with disease progression in human oral squamous cell carcinoma. Cancer Sci. 2018, 109, 2036-2045. [CrossRef] [PubMed]

75. Bonfitto, V.L.; Demasi, A.P.; Costa, A.F.; Bonfitto, J.F.; Araujo, V.C.; Altemani, A. High-grade transformation of adenoid cystic carcinomas: A study of the expression of GLUT1 glucose transporter and of mitochondrial antigen. J. Clin. Pathol. 2010, 63, 615-619. [CrossRef] [PubMed]

76. Wang, J.; Ye, C.; Chen, C.; Xiong, H.; Xie, B.; Zhou, J.; Chen, Y.; Zheng, S.; Wang, L. Glucose transporter GLUT1 expression and clinical outcome in solid tumors: A systematic review and meta-analysis. Oncotarget 2017, 8, 16875-16886. [CrossRef] [PubMed]

77. Kunkel, M.; Moergel, M.; Stockinger, M.; Jeong, J.H.; Fritz, G.; Lehr, H.A.; Whiteside, T.L. Overexpression of GLUT-1 is associated with resistance to radiotherapy and adverse prognosis in squamous cell carcinoma of the oral cavity. Oral Oncol. 2007, 43, 796-803. [CrossRef] [PubMed]

78. Shimanishi, M.; Ogi, K.; Sogabe, Y.; Kaneko, T.; Dehari, H.; Miyazaki, A.; Hiratsuka, H. Silencing of GLUT-1 inhibits sensitization of oral cancer cells to cisplatin during hypoxia. J. Oral Pathol. Med. 2013, 42, 382-388. [CrossRef] [PubMed]

79. Zhu, G.Q.; Tang, Y.L.; Li, L.; Zheng, M.; Jiang, J.; Li, X.Y.; Chen, S.X.; Liang, X.H. Hypoxia inducible factor $1 \alpha$ and hypoxia inducible factor $2 \alpha$ play distinct and functionally overlapping roles in oral squamous cell carcinoma. Clin. Cancer Res. 2010, 16, 4732-4741. [CrossRef] [PubMed]

80. Shimomura, H.; Sasahira, T.; Yamanaka, Y.; Kurihara, M.; Imai, Y.; Tamaki, S.; Yamakawa, N.; Shirone, N.; Hasegawa, M.; Kuniyasu, H.; et al. [ $\left.{ }^{18} \mathrm{~F}\right]$ fluoro-2-deoxyglucose-positron emission tomography for the assessment of histopathological response after preoperative chemoradiotherapy in advanced oral squamous cell carcinoma. Int. J. Clin. Oncol. 2015, 20, 308-316. [CrossRef] [PubMed]

81. Liang, X.; Yang, D.; Hu, J.; Hao, X.; Gao, J.; Mao, Z. Hypoxia inducible factor- $\alpha$ expression correlates with vascular endothelial growth factor-C expression and lymphangiogenesis/angiogenesis in oral squamous cell carcinoma. Anticancer Res. 2008, 28, 1659-1666. [PubMed]

82. De Lima, P.O.; Jorge, C.C.; Oliveira, D.T.; Pereira, M.C. Hypoxic condition and prognosis in oral squamous cell carcinoma. Anticancer Res. 2014, 34, 605-612. [PubMed]

83. Troiano, G.; Mastrangelo, F.; Caponio, V.C.A.; Laino, L.; Cirillo, N.; Lo Muzio, L. Predictive Prognostic Value of Tissue-Based MicroRNA Expression in Oral Squamous Cell Carcinoma: A Systematic Review and Meta-analysis. J. Dent. Res. 2018, 97, 759-766. [CrossRef] [PubMed] 
84. Wu, Y.; Zhang, L.; Zhang, L.; Wang, Y.; Li, H.; Ren, X.; Wei, F.; Yu, W.; Liu, T.; Wang, X.; et al. Long non-coding RNA HOTAIR promotes tumor cell invasion and metastasis by recruiting EZH2 and repressing E-cadherin in oral squamous cell carcinoma. Int. J. Oncol. 2015, 46, 2586-2594. [CrossRef] [PubMed]

85. Zhou, X.; Liu, S.; Cai, G.; Kong, L.; Zhang, T.; Ren, Y.; Wu, Y.; Mei, M.; Zhang, L.; Wang, X. Long Non Coding RNA MALAT1 Promotes Tumor Growth and Metastasis by inducing Epithelial-Mesenchymal Transition in Oral Squamous Cell Carcinoma. Sci. Rep. 2015, 5, 15972. [CrossRef] [PubMed]

86. Hong, Y.; He, H.; Sui, W.; Zhang, J.; Zhang, S.; Yang, D. Long non-coding RNA H1 promotes cell proliferation and invasion by acting as a ceRNA of miR138 and releasing EZH2 in oral squamous cell carcinoma. Int. J. Oncol. 2018, 52, 901-912. [PubMed]

87. Fish, J.E.; Santoro, M.M.; Morton, S.U.; Yu, S.; Yeh, R.F.; Wythe, J.D.; Ivey, K.N.; Bruneau, B.G.; Stainier, D.Y.; Srivastava, D. miR-126 regulates angiogenic signaling and vascular integrity. Dev. Cell 2008, 15, 272-284. [CrossRef] [PubMed]

88. Sasahira, T.; Kurihara, M.; Bhawal, U.K.; Ueda, N.; Shimomoto, T.; Yamamoto, K.; Kirita, T.; Kuniyasu, H. Downregulation of miR-126 induces angiogenesis and lymphangiogenesis by activation of VEGF-A in oral cancer. Br. J. Cancer 2012, 107, 700-706. [CrossRef] [PubMed]

89. Cai, J.; Tian, A.X.; Wang, Q.S.; Kong, P.Z.; Du, X.; Li, X.Q.; Feng, Y.M. FOXF2 suppresses the FOXC2-mediated epithelial-mesenchymal transition and multidrug resistance of basal-like breast cancer. Cancer Lett. 2015, 367, 129-137. [CrossRef] [PubMed]

90. Elsir, T.; Smits, A.; Lindstrom, M.S.; Nister, M. Transcription factor PROX1: Its role in development and cancer. Cancer Metastasis Rev. 2012, 31, 793-805. [CrossRef] [PubMed]

91. Liu, Y.; Ye, X.; Zhang, J.B.; Ouyang, H.; Shen, Z.; Wu, Y.; Wang, W.; Wu, J.; Tao, S.; Yang, X.; et al. PROX1 promotes hepatocellular carcinoma proliferation and sorafenib resistance by enhancing beta-catenin expression and nuclear translocation. Oncogene 2015, 34, 5524-5535. [CrossRef] [PubMed]

92. Park, K.J.; Cho, S.B.; Park, Y.L.; Kim, N.; Park, S.Y.; Myung, D.S.; Lee, W.S.; Kweon, S.S.; Joo, Y.E. Prospero homeobox 1 mediates the progression of gastric cancer by inducing tumor cell proliferation and lymphangiogenesis. Gastric Cancer 2017, 20, 104-115. [CrossRef] [PubMed]

93. Sasahira, T.; Kirita, T.; Nishiguchi, Y.; Kurihara, M.; Nakashima, C.; Bosserhoff, A.K.; Kuniyasu, H. A comprehensive expression analysis of the MIA gene family in malignancies: MIA gene family members are novel, useful markers of esophageal, lung, and cervical squamous cell carcinoma. Oncotarget 2016, 7, 31137-31152. [CrossRef] [PubMed]

94. Wang, F.; Tidei, J.J.; Polich, E.D.; Gao, Y.; Zhao, H.; Perrone-Bizzozero, N.I.; Guo, W.; Zhao, X. Positive feedback between RNA-binding protein $\mathrm{HuD}$ and transcription factor SATB1 promotes neurogenesis. Proc. Natl. Acad. Sci. USA 2015, 112, E4995-E5004. [CrossRef] [PubMed]

95. Takane, K.; Midorikawa, Y.; Yagi, K.; Sakai, A.; Aburatani, H.; Takayama, T.; Kaneda, A. Aberrant promoter methylation of PPP1R3C and EFHD1 in plasma of colorectal cancer patients. Cancer Med. 2014, 3, 1235-1245. [CrossRef] [PubMed]

96. Fatima, A.; Wang, Y.; Uchida, Y.; Norden, P.; Liu, T.; Culver, A.; Dietz, W.H.; Culver, F.; Millay, M.; Mukouyama, Y.S.; et al. Foxc1 and Foxc2 deletion causes abnormal lymphangiogenesis and correlates with ERK hyperactivation. J. Clin. Investig. 2016, 126, 2437-2451. [CrossRef] [PubMed]

97. Cui, Y.M.; Jiang, D.; Zhang, S.H.; Wu, P.; Ye, Y.P.; Chen, C.M.; Tang, N.; Liang, L.; Li, T.T.; Qi, L.; et al. FOXC2 promotes colorectal cancer proliferation through inhibition of FOXO3a and activation of MAPK and AKT signaling pathways. Cancer Lett. 2014, 353, 87-94. [CrossRef] [PubMed]

98. Cui, L.; Dang, S.; Qu, J.; Mao, Z.; Wang, X.; Zhang, J.; Chen, J. FOXC2 is up-regulated in pancreatic ductal adenocarcinoma and promotes the growth and migration of cancer cells. Tumour Biol. 2016, 37, 8579-8585. [CrossRef] [PubMed]

99. Gozo, M.C.; Jia, D.; Aspuria, P.J.; Cheon, D.J.; Miura, N.; Walts, A.E.; Karlan, B.Y.; Orsulic, S. FOXC2 augments tumor propagation and metastasis in osteosarcoma. Oncotarget 2016, 7, 68792-68802. [CrossRef] [PubMed]

100. Cui, Y.M.; Jiao, H.L.; Ye, Y.P.; Chen, C.M.; Wang, J.X.; Tang, N.; Li, T.T.; Lin, J.; Qi, L.; Wu, P.; et al. FOXC2 promotes colorectal cancer metastasis by directly targeting MET. Oncogene 2015, 34, 4379-4390. [CrossRef] [PubMed]

101. Sasahira, T.; Ueda, N.; Yamamoto, K.; Kurihara, M.; Matsushima, S.; Bhawal, U.K.; Kirita, T.; Kuniyasu, H. Prox1 and FOXC2 act as regulators of lymphangiogenesis and angiogenesis in oral squamous cell carcinoma. PLoS ONE 2014, 9, e92534. [CrossRef] [PubMed] 
102. Liu, Y.; Zhang, Y.; Wang, S.; Dong, Q.Z.; Shen, Z.; Wang, W.; Tao, S.; Gu, C.; Liu, J.; Xie, Y.; et al. Prospero-related homeobox 1 drives angiogenesis of hepatocellular carcinoma through selectively activating interleukin-8 expression. Hepatology 2017, 66, 1894-1909. [CrossRef] [PubMed]

103. Ragusa, S.; Cheng, J.; Ivanov, K.I.; Zangger, N.; Ceteci, F.; Bernier-Latmani, J.; Milatos, S.; Joseph, J.M.; Tercier, S.; Bouzourene, H.; et al. PROX1 promotes metabolic adaptation and fuels outgrowth of Wnt(high) metastatic colon cancer cells. Cell Rep. 2014, 8, 1957-1973. [CrossRef] [PubMed]

104. Yokobori, T.; Bao, P.; Fukuchi, M.; Altan, B.; Ozawa, D.; Rokudai, S.; Bai, T.; Kumakura, Y.; Honjo, H.; Hara, K.; et al. Nuclear PROX1 is Associated with Hypoxia-Inducible Factor $1 \alpha$ Expression and Cancer Progression in Esophageal Squamous Cell Carcinoma. Ann. Surg. Oncol. 2015, 22 (Suppl. 3), S1566-S1573. [CrossRef] [PubMed]

105. Saukkonen, K.; Hagstrom, J.; Mustonen, H.; Juuti, A.; Nordling, S.; Kallio, P.; Alitalo, K.; Seppanen, H.; Haglund, C. PROX1 and beta-catenin are prognostic markers in pancreatic ductal adenocarcinoma. BMC Cancer 2016, 16, 472. [CrossRef] [PubMed]

106. Laitinen, A.; Bockelman, C.; Hagstrom, J.; Kokkola, A.; Kallio, P.; Haglund, C. High PROX1 expression in gastric cancer predicts better survival. PLoS ONE 2017, 12, e0183868. [CrossRef] [PubMed]

107. Rodrigues, M.F.; de Oliveira Rodini, C.; de Aquino Xavier, F.C.; Paiva, K.B.; Severino, P.; Moyses, R.A.; Lopez, R.M.; DeCicco, R.; Rocha, L.A.; Carvalho, M.B.; et al. PROX1 gene is differentially expressed in oral cancer and reduces cellular proliferation. Medicine 2014, 93, e192. [CrossRef] [PubMed]

108. Arndt, S.; Bosserhoff, A.K. TANGO is a tumor suppressor of malignant melanoma. Int. J. Cancer 2006, 119, 2812-2820. [CrossRef] [PubMed]

109. Arndt, S.; Bosserhoff, A.K. Reduced expression of TANGO in colon and hepatocellular carcinomas. Oncol. Rep. 2007, 18, 885-891. [CrossRef] [PubMed]

110. Schmidt, J.; Riechers, A.; Bosserhoff, A.K. MIA-A new target protein for malignant melanoma therapy. Histol. Histopathol. 2013, 28, 421-426. [PubMed]

111. Abdelmohsen, K.; Hutchison, E.R.; Lee, E.K.; Kuwano, Y.; Kim, M.M.; Masuda, K.; Srikantan, S.; Subaran, S.S.; Marasa, B.S.; Mattson, M.P.; et al. miR-375 inhibits differentiation of neurites by lowering HuD levels. Mol. Cell. Biol. 2010, 30, 4197-4210. [CrossRef] [PubMed]

112. Samaraweera, L.; Grandinetti, K.B.; Huang, R.; Spengler, B.A.; Ross, R.A. MicroRNAs define distinct human neuroblastoma cell phenotypes and regulate their differentiation and tumorigenicity. BMC Cancer 2014, 14, 309. [CrossRef] [PubMed]

113. Wang, F.; Lu, J.; Li, S.; Huo, X.; Liu, X.; Du, X.; Li, C.; Wang, J.; Chen, Z. Application of Serum ELAVL4 (HuD) Antigen Assay for Small Cell Lung Cancer Diagnosis. Anticancer Res. 2017, 37, 4515-4522. [PubMed]

114. Sasahira, T.; Kurihara, M.; Yamamoto, K.; Ueda, N.; Nakashima, C.; Matsushima, S.; Bhawal, U.K.; Kirita, T.; Kuniyasu, H. HuD promotes progression of oral squamous cell carcinoma. Pathobiology 2014, 81, 206-214. [CrossRef] [PubMed]

115. Fenstad, M.H.; Johnson, M.P.; Loset, M.; Mundal, S.B.; Roten, L.T.; Eide, I.P.; Bjorge, L.; Sande, R.K.; Johansson, A.K.; Dyer, T.D.; et al. STOX2 but not STOX1 is differentially expressed in decidua from pre-eclamptic women: Data from the Second Nord-Trondelag Health Study. Mol. Hum. Reprod. 2010, 16, 960-968. [CrossRef] [PubMed]

116. Smith, J.J.; Deane, N.G.; Wu, F.; Merchant, N.B.; Zhang, B.; Jiang, A.; Lu, P.; Johnson, J.C.; Schmidt, C.; Bailey, C.E.; et al. Experimentally derived metastasis gene expression profile predicts recurrence and death in patients with colon cancer. Gastroenterology 2010, 138, 958-968. [CrossRef] [PubMed]

117. Sasahira, T.; Nishiguchi, Y.; Fujiwara, R.; Kurihara, M.; Kirita, T.; Bosserhoff, A.K.; Kuniyasu, H. Storkhead box 2 and melanoma inhibitory activity promote oral squamous cell carcinoma progression. Oncotarget 2016, 7, 26751-26764. [CrossRef] [PubMed]

118. Sasahira, T.; Kurihara, M.; Nishiguchi, Y.; Fujiwara, R.; Kirita, T.; Kuniyasu, H. NEDD 4 binding protein 2-like 1 promotes cancer cell invasion in oral squamous cell carcinoma. Virchows Arch. 2016, 469, 163-172. [CrossRef] [PubMed]

119. Zheng, M.Z.; Qin, H.D.; Yu, X.J.; Zhang, R.H.; Chen, L.Z.; Feng, Q.S.; Zeng, Y.X. Haplotype of gene Nedd4 binding protein 2 associated with sporadic nasopharyngeal carcinoma in the Southern Chinese population. J. Transl. Med. 2007, 5, 36. [CrossRef] [PubMed]

120. Tang, L.; Chen, F.; Pang, E.J.; Zhang, Z.Q.; Jin, B.W.; Dong, W.F. MicroRNA-182 inhibits proliferation through targeting oncogenic ANUBL1 in gastric cancer. Oncol. Rep. 2015, 33, 1707-1716. [CrossRef] [PubMed] 
121. Kurihara-Shimomura, M.; Sasahira, T.; Nakamura, H.; Nakashima, C.; Kuniyasu, H.; Kirita, T. Zinc finger AN1-type containing 4 is a novel marker for predicting metastasis and poor prognosis in oral squamous cell carcinoma. J. Clin. Pathol. 2018, 71, 436-441. [CrossRef] [PubMed]

122. Kang, H.S.; Roh, J.L.; Kim, M.J.; Cho, K.J.; Lee, S.W.; Kim, S.B.; Choi, S.H.; Nam, S.Y.; Kim, S.Y. Predictive factors for long-term survival in head and neck squamous cell carcinoma patients with distant metastasis after initial definitive treatment. J. Cancer Res. Clin. Oncol. 2016, 142, 295-304. [CrossRef] [PubMed]

123. Nakayama, A.; Nakaoka, H.; Yamamoto, K.; Sakiyama, M.; Shaukat, A.; Toyoda, Y.; Okada, Y.; Kamatani, Y.; Nakamura, T.; Takada, T.; et al. GWAS of clinically defined gout and subtypes identifies multiple susceptibility loci that include urate transporter genes. Ann. Rheum. Dis. 2017, 76, 869-877. [CrossRef] [PubMed]

124. Wang, W.; Xu, D.; Wang, B.; Yan, S.; Wang, X.; Yin, Y.; Wang, X.; Sun, B.; Sun, X. Increased Risk of Cancer in relation to Gout: A Review of Three Prospective Cohort Studies with 50,358 Subjects. Mediat. Inflamm. 2015, 2015, 680853. [CrossRef] [PubMed]

125. Sasahira, T.; Nishiguchi, Y.; Kurihara-Shimomura, M.; Nakashima, C.; Kuniyasu, H.; Kirita, T. NIPA-like domain containing 1 is a novel tumor-promoting factor in oral squamous cell carcinoma. J. Cancer Res. Clin. Oncol. 2018, 144, 875-882. [CrossRef] [PubMed]

126. Takeda, R.; Hirohashi, Y.; Shen, M.; Wang, L.; Ogawa, T.; Murai, A.; Yamamoto, E.; Kubo, T.; Nakatsugawa, M.; Kanaseki, T.; et al. Identification and functional analysis of variants of a cancer/testis antigen LEMD1 in colorectal cancer stem-like cells. Biochem. Biophys. Res. Commun. 2017, 485, 651-657. [CrossRef] [PubMed]

127. Ghafouri-Fard, S.; Ousati Ashtiani, Z.; Sabah Golian, B.; Hasheminasab, S.M.; Modarressi, M.H. Expression of two testis-specific genes, SPATA19 and LEMD1, in prostate cancer. Arch. Med. Res. 2010, 41, 195-200. [CrossRef] [PubMed]

128. Matsuyama, H.; Suzuki, H.I.; Nishimori, H.; Noguchi, M.; Yao, T.; Komatsu, N.; Mano, H.; Sugimoto, K.; Miyazono, K. miR-135b mediates NPM-ALK-driven oncogenicity and renders IL-17-producing immunophenotype to anaplastic large cell lymphoma. Blood 2011, 118, 6881-6892. [CrossRef] [PubMed]

129. Sasahira, T.; Kurihara, M.; Nakashima, C.; Kirita, T.; Kuniyasu, H. LEM domain containing 1 promotes oral squamous cell carcinoma invasion and endothelial transmigration. Br. J. Cancer 2016, 115, 52-58. [CrossRef] [PubMed]

130. Gjerstorff, M.F.; Andersen, M.H.; Ditzel, H.J. Oncogenic cancer/testis antigens: Prime candidates for immunotherapy. Oncotarget 2015, 6, 15772-15787. [CrossRef] [PubMed]

131. Lee, Y.; Kim, S.J.; Park, H.D.; Park, E.H.; Huang, S.M.; Jeon, S.B.; Kim, J.M.; Lim, D.S.; Koh, S.S. PAUF functions in the metastasis of human pancreatic cancer cells and upregulates CXCR4 expression. Oncogene 2010, 29, 56-67. [CrossRef] [PubMed]

132. Kim, S.J.; Lee, Y.; Kim, N.Y.; Hwang, Y.; Hwang, B.; Min, J.K.; Koh, S.S. Pancreatic adenocarcinoma upregulated factor, a novel endothelial activator, promotes angiogenesis and vascular permeability. Oncogene 2013, 32, 3638-3647. [CrossRef] [PubMed]

133. Kim, Y.H.; Moon, J.Y.; Kim, E.O.; Lee, S.J.; Kang, S.H.; Kim, S.K.; Heo, K.; Lee, Y.; Kim, H.; Kim, K.T.; et al. Efficient targeting and tumor retardation effect of pancreatic adenocarcinoma up-regulated factor (PAUF)-specific RNA replacement in pancreatic cancer mouse model. Cancer Lett. 2014, 344, 223-231. [CrossRef] [PubMed]

134. Cho, J.H.; Kim, S.A.; Park, S.B.; Kim, H.M.; Song, S.Y. Suppression of pancreatic adenocarcinoma upregulated factor (PAUF) increases the sensitivity of pancreatic cancer to gemcitabine and 5FU, and inhibits the formation of pancreatic cancer stem like cells. Oncotarget 2017, 8, 76398-76407. [CrossRef] [PubMed]

135. Song, J.; Lee, J.; Kim, J.; Jo, S.; Kim, Y.J.; Baek, J.E.; Kwon, E.S.; Lee, K.P.; Yang, S.; Kwon, K.S.; et al. Pancreatic adenocarcinoma up-regulated factor (PAUF) enhances the accumulation and functional activity of myeloid-derived suppressor cells (MDSCs) in pancreatic cancer. Oncotarget 2016, 7, 51840-51853. [CrossRef] [PubMed]

136. Sasahira, T.; Kurihara, M.; Nishiguchi, Y.; Nakashima, C.; Kirita, T.; Kuniyasu, H. Pancreatic adenocarcinoma up-regulated factor has oncogenic functions in oral squamous cell carcinoma. Histopathology 2017, 70, 539-548. [CrossRef] [PubMed]

137. Wen, D.; Liu, D.; Tang, J.; Dong, L.; Liu, Y.; Tao, Z.; Wan, J.; Gao, D.; Wang, L.; Sun, H.; et al. Malic enzyme 1 induces epithelial-mesenchymal transition and indicates poor prognosis in hepatocellular carcinoma. Tumour Biol. 2015, 36, 6211-6221. [CrossRef] [PubMed] 
138. Lu, Y.X.; Ju, H.Q.; Liu, Z.X.; Chen, D.L.; Wang, Y.; Zhao, Q.; Wu, Q.N.; Zeng, Z.L.; Qiu, H.B.; Hu, P.S.; et al. ME1 Regulates NADPH Homeostasis to Promote Gastric Cancer Growth and Metastasis. Cancer Res. 2018, 78, 1972-1985. [CrossRef] [PubMed]

139. Hanahan, D.; Weinberg, R.A. The hallmarks of cancer. Cell 2000, 100, 57-70. [CrossRef]

140. Reuter, C.W.; Morgan, M.A.; Eckardt, A. Targeting EGF-receptor-signalling in squamous cell carcinomas of the head and neck. Br. J. Cancer 2007, 96, 408-416. [CrossRef] [PubMed]

141. Ferris, R.L.; Blumenschein, G., Jr.; Fayette, J.; Guigay, J.; Colevas, A.D.; Licitra, L.; Harrington, K.; Kasper, S.; Vokes, E.E.; Even, C.; et al. Nivolumab for Recurrent Squamous-Cell Carcinoma of the Head and Neck. N. Engl. J. Med. 2016, 375, 1856-1867. [CrossRef] [PubMed]

(C) 2018 by the authors. Licensee MDPI, Basel, Switzerland. This article is an open access article distributed under the terms and conditions of the Creative Commons Attribution (CC BY) license (http://creativecommons.org/licenses/by/4.0/). 